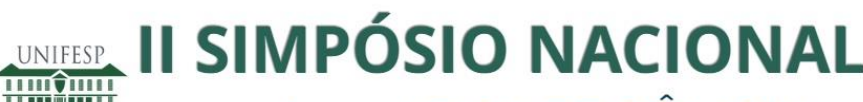

Desafios

\title{
Adolescer na escola: Onde estou? Aonde vou? E como vou?
}

\author{
Aline Maria Moreira dos Santos \\ Universidade Federal Juiz de Fora \\ Ana Lúcia de Almeida Vargas \\ Universidade Federal Juiz de Fora \\ Rosimeire Aparecida Neto Dias Villela \\ Universidade Federal Juiz de Fora \\ E-mail: villelarosimeire@gmail.com \\ Tatiane Souza Valadão \\ Universidade Federal Juiz de Fora \\ Venise Vieira Mendes \\ Universidade Federal Juiz de Fora
}

\section{Como citar:}

SANTOS, Aline Maria Moreira dos et al. Adolescer na escola: Onde estou? Aonde vou? E como vou?. In: II SIMPÓSIO NACIONAL SOBRE ADOLESCÊNCIA: VULNERABILIDADE, PROTAGONISMOS E DESAFIOS, 2. 2016,

São Paulo. Anais...[S.I]: 2016. p. 52-53.

DOI: http://dx.doi.org/10.22388/2525-5894.2016.031

Introdução: reconhecemos a educação como um processo social vivenciado e protagonizado por diferentes sujeitos sociais. E a escola como um espaço de aprendizado e de formação para a cidadania, por meio do convívio com as diferenças, e também espaço de expressão das diversas manifestações de questões sociais, emocionais e de aprendizagem. Acreditando que estas devem estar integradas e articuladas ao desenvolvimento da prática pedagógica e ao exercício da cidadania, efetivando-se institucionalmente, através de propostas coletivas de trabalho. Essas atividades desenvolvidas em parceria com vários atores da escola - coordenador (a) pedagógico (a), professor (a)s, estagiário (a)s/bolsistas e aluno (a)s - resultam em práticas de cunho transversal e interdisciplinares.

Objetivos: conhecer e intervir nas questões que se apresentam no contexto da escola e que interferem no processo educacional, considerando o atendimento das necessidades do (a)s aluno (a)s na escola, com base em sua fase de desenvolvimento e especificidades do ano escolar, de maneira a garantir sua formação integral.

Métodos: o trabalho está sendo realizado nesse ano letivo, através de reuniões de planejamento com o corpo docente do Colégio de Aplicação João XXIII/UFJF e a equipe do Núcleo de Apoio Escolar (NAE). O público-alvo são alunos do Ensino Fundamental II, com idades entre 11 e 16 anos. As estratégias adotadas são: rodas de conversas, oficinas pedagógicas, dinâmicas de grupos, produção de material informativo/educativo, visitas guiadas a espaços públicos entre outras. O eixo central dos trabalhos desenvolvidos, "Onde estou? Aonde vou? E como vou?", foi construído através do Projeto Coletivo de Trabalho do Colégio, dispositivo este adotado na Instituição para fomentar práticas interdisciplinares. 
Resultados: as oficinas realizadas nas turmas de Sextos Anos se nortearam pela temática "Adaptando a dinâmica do Ensino Fundamental II", onde se enfatizou o processo de reflexão e de adaptação a um segmento novo e seus possíveis estressores, a tolerância às diferenças e a construção do início de um processo de autonomia. Nos Sétimos Anos as ações se direcionaram para a reflexão/construção de "Habilidades de Vida", favorecendo a percepção das dificuldades no contexto escolar, disciplina e respeito ao outro, organização dos estudos e autonomia. Nas turmas de Oitavos Anos o "Adolescer e Escola" foi o mote, do qual foi discutido postura/atitude, regaste da finalidade da escola, respeito, ética, cidadania, disciplina, organização dos estudos, autonomia e desafios da adolescência como fase de novas experiências. Com os Nonos Anos o "Adolescer - Escola - Futuro" o foco do trabalho foi convivência em grupo, administração de conflitos e preparação para transição para o Ensino Médio.

Conclusões: esse formato de trabalho, construído a partir da colaboração coletiva de diversos atores e voltado para as suas reais demandas, vem impactando positivamente na realidade escolar e promovendo uma oportunidade de reflexões sobre questões educacionais e de desenvolvimento humano e social, de maneira a promover uma formação integral desses sujeitos.

Palavras-chaves: Adolescência. Escola. Projeto Coletivo. Interdisciplinaridade. 